Arab Univ. J. Agric. Sci., Ain Shams Univ., Cairo, Egypt 28(2), 663-672, 2020

Website: http://ajs.journals.ekb.eg

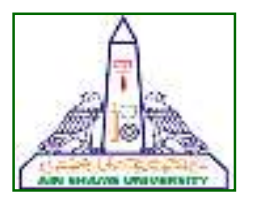

663

\title{
IMPACT OF PHYTASE SUPPLEMENTATION IN RESTRICTED CALCIUM AND PHOSPHORUS BROILER DIETS ON PERFORMANCE, BLOOD PARAMETERS AND BONE CHARACTERISTICS
}

\author{
Shabban ${ }^{1 *}$ Y.S., Abdel-Azeem ${ }^{1}$ F., Thabet $^{1}$ H.A. and Amal M. Hassan ${ }^{2}$ \\ 1- Poultry Production Dept., Fac. of Agric., Ain Shams Univ., P.O. Box 68, Hadayek Shoubra \\ 11241, Cairo, Egypt \\ 2- Desert Research Center, Ministry of Agriculture and Land Reclamation, Cairo, Egypt \\ ${ }^{*}$ Corresponding author: yassor saad@yahoo.com
}

Received 26 March, 2020

Accepted 13 May, 2020

\section{ABSTRACT}

Six weeks feeding trial using 210 one-day old unsexed Cobb 500 chicks was carried out to study the effects of addingphytase enzyme on growth performance, blood parametersand bone characteristics in broiler chicks. Three starter diets were used from 1 to 21 days; T100 $\{100 \%$ of Ca \& non-phytate phosphorus NPP requirements $(1.00 \% \mathrm{Ca}$ and $0.50 \%$ NPP $)\} ;$ T75 $\{75 \%$ of Ca \& NPP requirements (0.75\% Ca and $0.38 \%$ NPP) $\}$ and T50 $\{50 \%$ of $\mathrm{Ca} \&$ NPP requirements $(0.51 \% \mathrm{Ca}$ and $0.25 \% \mathrm{NPP})\}$. Three grower diets were used from 22 to 42 days; $\mathrm{T} 100\{100 \%$ of $\mathrm{Ca} \&$ NPP requirements $(0.91 \% \mathrm{Ca}$ and $0.46 \%$ NPP) $\}$; T75 $\{75 \%$ of Ca \& NPP requirements( $0.68 \% \mathrm{Ca}$ and $0.34 \% \mathrm{NPP})\}$ and $\mathrm{T} 50\{50 \%$ of $\mathrm{Ca} \&$ NPP requirements $(0.45 \% \mathrm{Ca}$ and $0.23 \%$ NPP)\}. Seven dietary treatments were distributed according to diets fed consecutively during starter and grower phases as; (100/100) fed starter T100 then grower T100; (100/75) fed starter T100 then grower T75; (100/50) fed starter T100 then grower T50; (75/75) fed starter T75 then grower T75; $(75 / 50)$ fed starter T75 then grower T50 and (50/50) fed starter T50 then grower T50.All diets added phytase enzyme (FTU 10000/Ton). Each treatment comprised of 30 chicks in 3 replicates of 10 chicks each. Results showed that live body weight and weight gain did not significantly affected by restricted Ca and NPP diets at starter period, where weight gain was significantly affected at grower period. Birds group received diet containing 100/75 with phytase (T3) gave the highest significant values for LBW and BWG, then 50/50 with phytase (T7) as compared with the other experimental groups during the grower and overall periods. Feed
\end{abstract}

consumption and conversion ratio values were no significant differences among groups fed different dietary treatments during starter and grower phases. Plasma $\mathrm{P}$ concentrations was significantly affected however plasma $\mathrm{Ca}$ concentrations, GOT and GPT values were not significantly affected by the reduction of dietary $\mathrm{Ca}$ and NPP with adding phytase. Percentages of tibia ash, $\mathrm{Ca}$ and $\mathrm{P}$ were significantly affected by dietary treatments. Supplementation of phytasehas a significant effect ontibia breaking strength, while supplementation of phytase hasn't any effect on tibia Seedorindex. It is obvious that, the best performance was seen with (100/75) diet without any adverse effect on productive performance, blood parameters and most of tibia measurements and chemical composition.

Keywords: calcium, phosphorus, phytate, NPP, broilers, performance, blood, tibia

\section{INTRODUCTION}

The general efficiency of dietary $P$ utilization (plant origin) is relatively low (20-27\%), and a significant amount of $P$ is contained in litter and manure (Ferket et al 2002).

Phosphorus is an essential mineral for poultry because it is play an important role in metabolic and structural processes, and is an essential mineral to achieve maximal potential in growth performance. However, plant phytate binds to minerals and other nutrients to strictly decrease nutrient availability and harmfully affect digestion and absorption processes. To solve this problem, phytase, an exogenous enzyme, is commonly used as a feed additive 
to release phytate-bound P. Dietary supplementation with exogenous phytase is an effective method of improving $P$ digestibility (Walk et al 2013; Selle and Ravindran, 2007; Adeola and Cowieson, 2011).

Exogenous phytase enzyme is incorporatedrecently in poultry diets not only to reduce phosphorus supplementation, but also to liberate minerals, particularly calcium, amino acids and carbohydrates by the hydrolysis of phytate complex (Oluyinka et al 2007; Slominski, 2011). However, nutrient utilization can also be affected by extra factors, such as dietary calcium, phosphorus, protein, and energy levels, intestinal $\mathrm{pH}$, environmental temperature, etc. Consequently, inorganic phosphorus is added to coverbird's requirements of phosphorus.

The current study aimed to investigate theeffect of $\mathrm{Ca}$ and non-phytate phosphorus (NPP) restriction in broiler diets supplemented with phytase enzyme on performance, some blood components and bone measurements.

\section{MATERIALS AND METHODS}

\section{Experimental diets and birds}

The current study was carried out at the Poultry Nutrition Unit, Poultry Production Department, Faculty of Agriculture, Ain Shams University. Two hundred and ten chicks were randomly assigned to seven dietary experimental treatments (7 treatments $\times 3$ replicates $\times 10$ chicks in each) and were housed in three-tiered batteries equipped with feeders and drinking nipples. Feed and water were offeredad-libitum and chicks were kept under similar environmental and managerial conditions during the period 1-42 days of age. Three different starter diets (fed from 1 to 21 days); diet (100) contained standard requirements suggested by the guidebook of Cobb500 broilers of $\mathrm{Ca}$ and NPP during starter period; diet (75) contained $75 \%$ of Ca and NPP standard requirements and diet (50) contained $50 \%$ of $\mathrm{Ca}$ and NPP standard requirements. Three different grower diets (fed from 22 to 42 days); diet (100) contained standard requirements suggested by the guidebook of Cobb 500 broilers of $\mathrm{Ca}$ and NPP during grower period; diet (75) contained $75 \%$ of $\mathrm{Ca}$ and NPP standard requirements and diet (50) contained $50 \%$ of $\mathrm{Ca}$ and NPP standard requirements. Seven dietary treatments were distributed according to diets fed consecutively during starter and grower phases as; $(100 / 100, \mathrm{T1}) ;(100 / 100, \mathrm{~T} 2)$ with phytase; (100/75, T3) with phytase; (100/50, T4) with phytase; $(75 / 75, T 5)$ with phytase; $(75 / 50, T 6)$ with phytase and (50/50, T7) with phytase. Diets listed in Table (1), were formulated ensuring enough supply of nutrients suggested by the guidebook of Cobb500 broilers to be isocaloric and isonitrogenous according to NRC (1994) and were offered in mash form.

\section{Growth performance}

Live body weight (LBW) of each replicate was recorded in the early morning. The average body weight gain (BWG) was calculated per replicate by subtracting the initial body weight of a bird in a certain stage from the final one in the same stage. Average of daily feed consumption (DFC) was calculated from the difference between the weekly amount of feed provided for each replicate within treatments and the residual quantity for the same replicate. Feed conversion ratio (FCR) was calculated in different stages as the amount of feed consumed, in grams, in a certain stage which is required to produce out one gram of weight gain in the same stage.

\section{Blood plasma}

At 42 days of age, six birds from each treatment having body weight around the average of their treatment were chosen and sacrificed by severing the carotid artery and the jugular vein. Blood samples were collected simultaneously with slaughtering in heparinized tubes. Blood samples were immediately centrifuged at $3000 \mathrm{rpm}$ for 10 minutes to separate plasma. Plasma calcium, phosphorus, (Tietz, 1995) Aspartate transaminase (AST) and Alanine transaminase (ALT) were carried out. Plasma GOT and GPT (AST and plasma ALT) were determined using a colorimetric method according to Reitman and Frankel (1957).

\section{Bone measurements}

Tibia of both legs were removed, cleaned of flesh and all soft tissue, cartilage caps were removed, oven-dried and dry tibia weight was recorded according to the method described by Samejima (1990). The Seedor index (SI) was obtained when a tibia dry weight (in grams) is divided by its length (in centimeters), as proposed by Seedor et al (1991). It represents an indication of bone density: the higher the value, the denser the bone. The tibia samples were ground for procedure of the chemical analysis; bone ash was determined colorimetrically. 

Diets on Performance, Blood Parameters and Bone Characteristics

Table 1. Feed ingredients and chemical composition of experimental diets

\begin{tabular}{|l|c|c|c|c|c|c|}
\hline \multirow{2}{*}{ Ingredients\% } & \multicolumn{3}{|c|}{ Starter } & \multicolumn{3}{c|}{ Grower } \\
\cline { 2 - 7 } & $\mathbf{1 0 0 \%}$ & $\mathbf{7 5 \%}$ & $\mathbf{5 0 \%}$ & $\mathbf{1 0 0 \%}$ & $\mathbf{7 5 \%}$ & $\mathbf{5 0 \%}$ \\
\hline Yellow corn & 56.68 & 57.14 & 58.52 & 63.95 & 64.31 & 65.10 \\
Soybean meal (44 \% CP) & 31.15 & 33.35 & 34.00 & 25.18 & 27.70 & 29.15 \\
Corn gluten meal (60\%CP) & 5.60 & 4.00 & 3.35 & 4.10 & 2.20 & 1.05 \\
Vegetable Oil & 2.00 & 2.00 & 1.65 & 2.50 & 2.50 & 2.35 \\
Ca Carbonate & 1.60 & 1.17 & 0.77 & 1.47 & 1.08 & 0.70 \\
MCP\# & 1.85 & 1.25 & 0.64 & 1.65 & 1.10 & 0.56 \\
NaCl & 0.30 & 0.30 & 0.30 & 0.30 & 0.30 & 0.30 \\
Premix* & 0.30 & 0.30 & 0.30 & 0.30 & 0.30 & 0.30 \\
HCI Lysine & 0.28 & 0.24 & 0.22 & 0.31 & 0.26 & 0.23 \\
DL- Methionine & 0.24 & 0.25 & 0.25 & 0.24 & 0.25 & 0.26 \\
\hline Total & $\mathbf{1 0 0}$ & $\mathbf{1 0 0}$ & $\mathbf{1 0 0}$ & $\mathbf{1 0 0}$ & $\mathbf{1 0 0}$ & $\mathbf{1 0 0}$ \\
\hline Calculated analysis & & & & & & \\
\hline CP \% & 22 & 22.01 & 22.01 & 19.06 & 19.02 & 19.01 \\
ME (Kcal/Kg) & 2999 & 3004 & 3006 & 3103 & 3101 & 3102 \\
Calcium \% & 1.01 & 0.754 & 0.51 & 0.91 & 0.68 & 0.45 \\
NPP* & 0.51 & 0.382 & 0.25 & 0.46 & 0.34 & 0.23 \\
Lysine\% & 1.32 & 1.327 & 1.32 & 1.2 & 1.19 & 1.19 \\
Methionine \% & 0.62 & 0.617 & 0.61 & 0.57 & 0.57 & 0.57 \\
Meth. + Cyst. \% & 0.98 & 0.98 & 0.98 & 0.89 & 0.89 & 0.89 \\
\hline
\end{tabular}

\#MCP: mono-calcium phosphate, ${ }^{*}$ NPP: non-phytate phosphorus.

${ }^{* \star} T$ The premix contains: Vitamins: A: 12000000 IU; Vit. D3 $2000000 \mathrm{IU} ; \mathrm{E}: 10000 \mathrm{mg} ; \mathrm{K}_{3}: 2000 \mathrm{mg} ; \mathrm{B}_{1}: 1000$ mg; $B_{2}: 5000$ mg; $B_{6}: 1500$ mg; $B_{12}: 10$ mg; Biotin: 50 mg;Choline chloride: 250000 mg; Pantothenic acid: 10000 mg; Nicotinic acid: 30000 mg; Folic acid: 1000 mg; Minerals: Mn: 60000 mg; Zn: 50000 mg; Fe: $30000 \mathrm{mg}$; Cu: $10000 \mathrm{mg}$; I: $1000 \mathrm{mg}$; Se: $100 \mathrm{mg}$ and Co: $100 \mathrm{mg}$.

Tibia breaking strength was determined using the method prescribed by Flemming et al (1998) by using an Instron Universal material testing machine.

\section{Calcium and phosphorus retention}

At the end of the experimental period, six samples of excreta were weighed and ground prior to analysis for calcium and phosphorus as described by AOAC (1990).

\section{Statistical Analysis}

Data were subjected to one-way ANOVA analysis of variance General Linear Model (GLM) procedure of SAS software SAS (1998) user's guide according to the following model:

$Y_{i j}=\mu+T_{i}+e_{i j}$ Where; $\mu=$ overall mean, $T_{i}=$ dietary treatment, $e_{i j}=$ experimental error. Individual effects of dietary treatments were compared using Duncan (1955) multiple range tests at a level equal to 0.05 .

Retention was calculated as follows:

$\%$ Retention $=($ consumed - excreted $) \times 100 /$ consumed, Pintar et al (2005) 


\section{RESULTS AND DISCUSSION}

\section{Growth performance}

Results presented in Table (2) showed no significant $(P>0.05)$ differences among groups fed different dietary treatments in live body weight (LBW) and weight gain (WG) values during starter phase. However, values of overall LBW and WG showed significant $(P>0.01)$ differences among groups fed different diets. On the other hand, birds group received diet containing 100/75 with phytase (T3) gave the highest significant values for LBW and BWG as compared with the other experimental groups during the grower and overall periods. Feed consumption (FC) values presented in Table (2) showed no significant $(P>0.05)$ differences among groups fed different dietary treatments during starter and grower phases. Feed conversion ratio (FCR) values shown in Table (2) demonstrate no significant $(P>0.05)$ differences among groups fed different dietary treatments during starter and grower phases. As shown in Table (2), when comparing $(100 / 100)$ with $(75 / 75)$ or $(50 / 50)$, it is comprehensible that no adverse effects were observed on FC and FCR when calcium and phosphorus levels were reduced in gentle approach between starter and grower phases (Abdelaziz, 2011). In addition, as the degree of diminishing $\mathrm{Ca}$ and NPP levels is less steep approach, the negative effects of feeding diets based on these treatments are relatively declined.

Our findings are in harmony with Thacker et al (2013) and Jiang et al (2013) where feed efficiency in broiler chicks was similar despite differences in the dietary available $P$.

Data of productive performance are commonly, in agreement with the results of Abdelaziz (2011) who stated that using low levels if both $\mathrm{Ca}$ and NPP diets gave results nearly matching those of control group. Current results are also in conformity with those of Thabet (2010); Dhandu and Angel (2003) and Angel et al (2000).

The fact that birds fed (100/75) diet presented performance similar to those fed (100/100) diet could be explained by the fact that broilers fed the diet with low NPP and Ca demonstrated a certain ability to adapt to theseminerals deficiency (Yan et al 2005).

\section{Blood parameters}

Plasma $\mathrm{Ca}$ and Pconcentrationsand GOT and GPTactivity are presented in Table (3). Results showed no significant $(P>0.05)$ differences among groups fed different dietary treatments in plasma $\mathrm{Ca}$ concentrations andGOT and GPT activity values. Plasma $P$ values showed that deviations between different treatments have been come out at the end of grower period. Data indicated that birds fed $(100 / 100)$ without phytasediet have shown significantly higher $(\mathrm{P} \leq 0.05)$ values of plasma $\mathrm{P}$ concentration. During the grower phase, birds fed $(75 / 50$, T6) diet have significantly $(P \leq 0.05)$ the lowest $P$ value as compared toamong all treatments, while those fed (100/100) diet with or without phytase, whereas birds fed (100/75), (100/50), (75/75) diet have shown significantly similar values. Plasma GOT and GPT values obtained at the end of grower period indicated no significant differences between all sevengroups. Data of plasma calcium, phosphorus,GOT and GPTagreed with those obtained by Abdelaziz (2011) and Boluetal. (2006). When the blood $\mathrm{Ca}$ decreases, parathyroid hormone (PTH) motivates the transfer of $\mathrm{Ca}$ and $\mathrm{P}$ from body skeleton to blood and impresses kidneys to produce endogenous cholecalciferol which affects small intestine and increases $\mathrm{Ca}$ and $\mathrm{P}$ absorption (Kheiri and Rahmani, 2006).

\section{Bone composition and measurements}

Data of tibia ash percentage are presented in Table (4). The data showed that birds of T7 had recorded significantly $(P \leq 0.05)$ lowest values of tibia ash percentage when compared to those others. In addition, it observed that reducing phosphorus intake of bird's diets resulting in linearly decreased $(P<0.05)$ of tibia ash percentage. These results are in-agreement with Thabet (2010) who found that tibia ash of broilers fed low Calcium and Available Phosphorus diets was lower than those of broilers fed control diet. On the other hand, broilers fed diet containing low level of phytase showed higher $\mathrm{P}$ and $\mathrm{Ca}$ content within the tibia than broilers fed diet containing high level of phytase.

Data of tibia Ca percentage showed that birds fed $(100 / 75, T 3)$ diet had significantly $(P \leq 0.05)$ higher values compared to those fed $(100 / 100, T 1)$ without phytase or $(100 / 100, T 2)$ with phytase.

Data of tibia $P$ percentage showed no significant $(P>0.05)$ differences between groups except $\mathrm{T} 1$ and T3. Tibia P\% of broiler had diet (100/75) was lower significantly than that (100/100) without phytase. In addition, it is noticed that birds fed (100/75) diet appeared appreciably equivalent to those fed T2 $(100 / 100)$ or T5 (75/75) and T6 (75/50) diets. These results agree with Thabet et al (2014). Results were generally in harmony with Abdelaziz (2011) and Yan et al (2005), bone mineral content of birds at 
Table 2. Effect of different dietary treatments on productive performance of broiler chicks

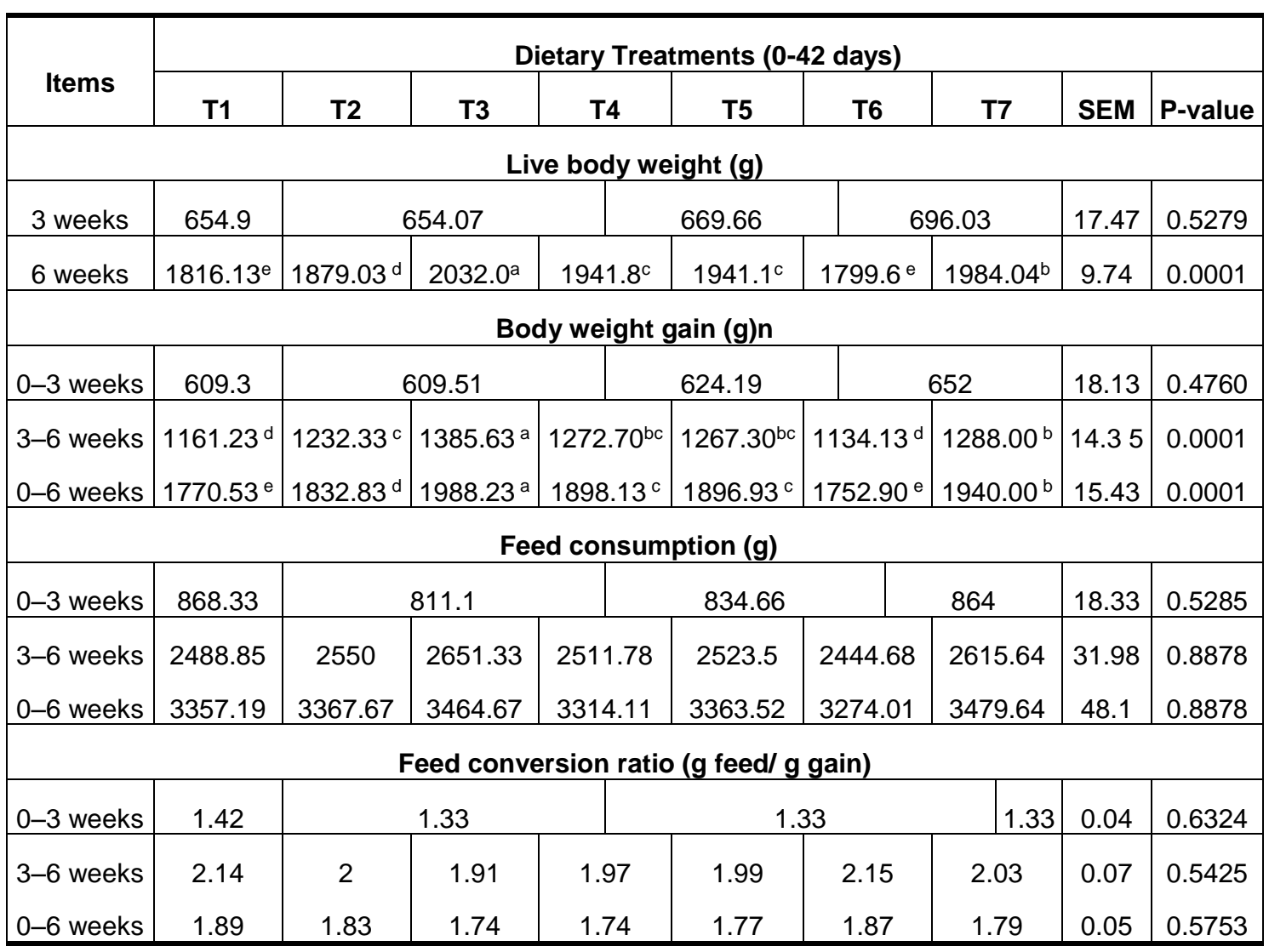

a, b, c. d. e Means within the same row with different superscripts are significantly different. SEM = standard error of means.

Table 3. Effect of different dietary treatments on some blood plasma parameters at 42 days of age

\begin{tabular}{|c|c|c|c|c|c|c|c|c|c|}
\hline \multirow{2}{*}{ Items } & \multicolumn{10}{|c|}{ Dietary Treatments } \\
\cline { 2 - 9 } & T1 & T2 & T3 & T4 & T5 & T6 & T7 & SEM & P-value \\
\hline Calcium (mg/dl) & 8.9 & 8.92 & 8.9 & 8.79 & 8.54 & 8.76 & 8.8 & 0.21 & 0.8941 \\
Phosphorus (mg/dl) & $7.64^{\mathrm{a}}$ & $7.53^{\mathrm{ab}}$ & $7.38^{\mathrm{b}}$ & $7.46^{\mathrm{b}}$ & $7.47^{\mathrm{b}}$ & $6.88^{\mathrm{d}}$ & $7.18^{\mathrm{c}}$ & 0.05 & 0.0001 \\
GOT (U/dl) & 227.53 & 227.2 & 226.93 & 227.23 & 226.81 & 226.86 & 225.22 & 1.14 & 0.8424 \\
GPT (U/dl) & 14.66 & 14.69 & 14.68 & 14.67 & 14.67 & 14.62 & 14.64 & 0.04 & 0.9467 \\
\hline
\end{tabular}

a, b, c. dMeans within the same row with different superscripts are significantly different. SEM = standard error of means. 
Table 4. Effect of different dietary treatments on some aspects of bone composition and measurements at 42 days of age

\begin{tabular}{|c|c|c|c|c|c|c|c|c|c|}
\hline \multirow{2}{*}{ Items } & \multicolumn{9}{|c|}{ Dietary Treatments } \\
\hline & T1 & T2 & T3 & T4 & T5 & T6 & T7 & SEM & P-value \\
\hline \multicolumn{10}{|c|}{ Bone Composition } \\
\hline Tibia Ash \% & $40.00^{a}$ & $36.33^{a b}$ & $34.67^{a b}$ & $33.35^{\mathrm{b}}$ & $33.33^{b}$ & $33.31^{\mathrm{b}}$ & $30.23^{c}$ & 0.22 & 0.0002 \\
\hline Tibia Ca \% & $19.99^{c}$ & $20.13^{b c}$ & $22.53^{a}$ & $20.95^{\mathrm{cb}}$ & $19.70^{c}$ & $20.11^{\mathrm{cb}}$ & $21.32^{\mathrm{ab}}$ & 0.38 & 0.0015 \\
\hline Tibia P \% & $13.92^{\mathrm{a}}$ & $11.15^{\mathrm{bc}}$ & $10.05^{c}$ & $11.85^{b}$ & $11.25^{b c}$ & $11.26^{b c}$ & $11.53^{b}$ & 0.34 & 0.0005 \\
\hline \multicolumn{10}{|c|}{ Bone Measurements } \\
\hline $\mathrm{TBS}\left(\mathrm{Kg} / \mathrm{cm}^{2}\right)$ & $31.63^{a}$ & $31.10^{\mathrm{a}}$ & $30.07^{b}$ & $29.80^{b}$ & $30.13^{b}$ & $29.50^{b}$ & $29.97^{b}$ & 0.23 & 0.0004 \\
\hline $\begin{array}{l}\text { Tibia Seedor Index } \\
\text { (SI) }\end{array}$ & 1.09 & 1.03 & 1.17 & 1.01 & 1.02 & 1.11 & 1.18 & 0.08 & 0.6562 \\
\hline
\end{tabular}

a, b, c., d. eMeans within the same row with different superscripts are significantly different. Seedor et al (1991). SEM = standard error of means. TBS= Tibia breaking strength

$(100 / 100)$ treatment had the highest values. The authors indicated that when expressing tibia ash $(\mathrm{g})$ in relation to consumed NPP or $\mathrm{Ca}(\mathrm{g})$, birds fed $(100 / 75)$ had higher ash weight per gram of NPP or Ca consumed at all ages as compared with that of birds fed the $(100 / 100)$ treatments. This could be attributed to considerable adaptation to $\mathrm{P}$ and $\mathrm{Ca}$ restriction in (100/75) birds. These observations agreed with Coto et al (2008a and b), Fritts and Waldroup (2003).

Tibia breaking strength (TBS) was higher significantly $(P>0.05)$ values for broilers fed $(100 / 100)$ diets with or without phytase.Data were agreement with Xian et al (2013)who found that supplementation of phytase significantly improved ash percentage and $P$ content of tibia at 42 days of age and tended to increase breaking strength of chickens at 42 days of age.

Tibia breaking strength reflects the rigidity of bones. The low breaking strength values in medium NPP treatment on day 42 meant that the tibia was more fragile, thus likely indicating the diet was deficient in P. Tibia Seedor index (SI) values showed that birds have non-significant $(P \geq 0.05)$ differences among all treatments. Data of bone measurements were generally in harmony with Abdelaziz (2011).

\section{Calcium and phosphorus retention}

Calcium andphosphorus excretion and retention of broiler chicks fed different dietary treatments are summarized in Table (5). Broilers fed diet of T1 (100/100; negative control; without phytase) had the highest significant records of $\mathrm{P}$ and $\mathrm{Ca}$ excretion then broilers of T2 (100/100; positive control; with phytase) than those of other groups. Decreasing dietary $P$ showed decreasing of $P$ and $\mathrm{Ca}$ excretion which reflect on enhancement retention of both $P$ and $\mathrm{Ca}$ retention. These results mean that the unused portions of the phosphorus as well as the indigestible phytate are excreted resulting in high percent of $P$ in manure in broilers fed $\mathrm{T} 1$ while adding phytase for others groups resulting in decreasing $P$ excretion which reflected on $\mathrm{Ca}$ and $\mathrm{P}$ retention percentage. The results are confirmed by results of El-Sherbiny et al (2010) that founddecreasing dietary dicalcium phosphate (DCP) showed significant decrease in the excreted $\mathrm{Ca}$ and $\mathrm{P}$, using enzymes in poultry diets improves availability of certain nutrients, mainly phosphorus and calcium, diminishing its presence on excreta. In addition, Cowieson et al (2004) reported that high percent of phytate consumption in birds' diets is recovered in the excretawhich reflect on increasing cost of the diets and contributes to environmental pollution (Pallauf et al 1994; Musapuor et al 2006). So, phosphorus is one of the most effective factors in environment contamination. Hence, when feeding broiler chickens $\mathrm{P}$ deficient diets, a reduction in the dietary $\mathrm{Ca}$ content lead to an improvement in $\mathrm{P}$ digestibility, bone $P$ and performance (Walk et al 2012). The increased broiler chick's performance could also attribute to increased activity of endogenous phytase at lower Ca level. Similarly, Bradbury et al (2014) noted that birds given a ration with $\mathrm{Ca}$ : NPP ratio of 4:1 had the lowest tibia ash and standing ability in comparison to lower ratios, resulting in impaired mobility. 
Table 5. Effect of different dietary treatments on calcium and phosphorus retention at 42 days of age

\begin{tabular}{|c|c|c|c|c|c|c|c|c|c|}
\hline \multirow{2}{*}{ Items } & \multicolumn{7}{|c|}{ Dietary Treatments } \\
\cline { 2 - 9 } & T1 & T2 & T3 & T4 & T5 & T6 & T7 & SEM & P-value \\
\hline P Excretion \% & $47.12^{\mathrm{a}}$ & $44.32^{\mathrm{b}}$ & $40.37^{\mathrm{c}}$ & $26.29^{\mathrm{d}}$ & $27.04^{\mathrm{d}}$ & $23.35^{\mathrm{e}}$ & $24.60^{\mathrm{ed}}$ & 1.48 & 0.0001 \\
P Retention \% & $52.88^{\mathrm{e}}$ & $55.68^{\mathrm{d}}$ & $59.63^{\mathrm{c}}$ & $73.71^{\mathrm{b}}$ & $72.96^{\mathrm{b}}$ & $76.65^{\mathrm{a}}$ & $75.40^{\mathrm{ab}}$ & 1.48 & 0.0001 \\
Ca Excretion \% & $50.09^{\mathrm{a}}$ & $54.35^{\mathrm{a}}$ & $35.42^{\mathrm{b}}$ & $24.01^{\mathrm{cd}}$ & $21.85^{\mathrm{d}}$ & $29.92^{\mathrm{cd}}$ & $22.96^{\mathrm{cd}}$ & 2.36 & 0.0001 \\
\hline & & & & & & & & & \\
CaRetention \% & $49.90^{\mathrm{d}}$ & $54.65^{\mathrm{d}}$ & $64.58^{\mathrm{c}}$ & $75.99^{\mathrm{ab}}$ & $78.15^{\mathrm{a}}$ & $70.08^{\mathrm{bc}}$ & $77.04^{\mathrm{ab}}$ & 2.36 & 0.0003 \\
\hline
\end{tabular}

a, b, c., d. eMeans within the same row with different superscripts are significantly different. SEM = standard error of means.

\section{CONCLUSION}

We can conclude that reducerequirements of both $\mathrm{Ca}$ and NPP in broiler diets byabout $75 \%$ with adding phytase as in (100/75) treatment, to save cost of broiler feed decreasing as well as without any adverse effects on performance, blood and bone features.

\section{REFERENCES}

Abdelaziz M.A.M. 2011. Nutritional studies on phosphorus in broiler diets. Ph.D. Thesis, Faculty of Agriculture, Ain Shams University, Egypt. pp. 261-274.

Adeola O. and Cowieson A.J. 2011. Opportunities and challenges in using exogenous enzymes to improve non ruminant animal production. J. Anim. Sci., 89, 3189-3218.

Angel R., Applegate T.J. and Christman M. 2000. Effect of dietary non-phytate phosphorus (nPP) on performance and bone measurements in broilers fed a four-phase feeding system. Poultry Science, 79(Suppl. 1), 21-22.

AOAC 1990. Association of Official Analytical Chemists. Official methods of analysis $15^{\text {th }} \mathrm{ed}$. Volume 2, Washington D.C., USA.

Bolu S.A., Adebayo C.A., Aklilu A. and Aderolu Z. 2006. Increasing dietary cholecalciferol for improved broiler marketability. J. of Animal Nutrition and Feed Technology, 6, 223-228.

Bradbury E.J., Wilkinson S.J., Cronin G.M., Thomson P.C., Bedford M.R. and Cowieson A.J. 2014. Nutritional geometry of calcium and phosphorus nutrition in broiler chicks. Growth performance, skeletal health and intake arrays. Animal, pp. 1071-1079.

Coto C., Yan F., Cerrate S., Wang Z., Sacakli P., Waldroup P.W., Halley J.T., Wiernusz C.J. and Martinez A. 2008 a. Effects of dietary levels of calcium and nonphytate phosphorus in broiler starter diets on live performance, bone development and growth plate conditions in male chicks fed a wheat-based diet. Int. J. of Poultry Sci., 7, 101-109.

Coto C., Yan F., Cerrate S., Wang Z., Sacakli P., Halley J.T., Wiernusz C.J., Martinez A. and Waldroup P.W. 2008 b. Effects of dietary levels of calcium and nonphytate phosphorus in broiler starter diets on live performance, bone development and growth plate conditions in male chicks fed a corn-based diet. Int. J. of Poultry Sci., 7, 638-645.

Cowieson A.J., Acamovic T. and Bedford M.R. 2004. The effect of phytic acid and phytase on the digestibility of maize starch for growing broiler chickens. Poult. Sci., 83(Suppl. 1), 1860-1867.

Dhandu A.S. and Angel R. 2003. Broiler non-phytinphosphorus requirement in the finisher and withdrawal phases of a commercial four-phase feeding system. Poultry Sci., 82, 1257-1265.

Duncan D.B. 1955. Multiple range and Multiple F tests. Biometrics, 11, 1-42.

El-Sherbiny A.E., Hassan H.M.A., Abd-Elsamee M.O., Samy A. and Mohamed M.A. 2010. Performance, Bone Parameters and Phosphorus Excretion of Broilers Fed Low Phosphorus Diets Supplemented with Phytase from 23 to 40 Days of Age. Int. J. of Poultry Sci., 9(10), 972-977. 
Ferket P., Van Heugten E., Van Kempen T. and Angel R. 2002. Nutritional strategies to reduce environmental emissions from nonruminants. J. of Animal Sci., 80(2), 168-182.

Fleming K., Johnston P., Zwartz D., Yokoyama Y., Lambeck K. and Chappell J. 1998. Refining the eustatic sea-level curve since the Last Glacial Maximum using far- and intermediate-field sites. Earth and Planetary Sci. Letters 163 (1-4), 327-342.

Fritts C.A. and Waldroup P.W. 2003. Effect of source and level of vitamin $D$ on live performance and bone development in growing broilers. J. of Applied Poultry Res., 12, 45-52.

Jiang X.R., Luo F.H., Qu M.R., Bontempo V., Wu S.G., Zhang H.J., Yue H.Y. and Qi G.H. 2013. Effects of non-phytate phosphorus levels and phytase sources on growth performance, serum biochemical and tibia parameters of broiler chickens Ital. J. Anim. Sci., 12, 375-380.

Kheiri F. and Rahmani H.R. 2006. The effect of reducing calcium and phosphorous on broiler performance. Int. J. of Poultry Sci., 5, 22-25.

Musapuor A., Afsharmanesh M. and Moradi H. 2006. The Use of microbial phytase for decrease of pollutant environmental poultry excreta phosphorus. Int. J. Agric. Biol., 8, 35-37.

NRC 1994. National Research Council. Nutrient Requirements of Poultry $9^{\text {th }} \mathrm{ed}$. Composition of poultry feedstuffs. National Academy Press, Washington, DC, USA, pp. 61-75.

Oluyinka A.O., Cowieson A.J. and Adeola O. 2007. Energy utilization and growth performance of broilers receiving diets supplemented with enzymes containing carbohydrase or phytase activity individually or in combination. British J. of Nutrition; 99, 682-690.

Pallauf J., Rimbach G., Pippig S., Schindler B. and Most E. 1994. Effect of phytase supplementation to a phytate-rich diet based on wheat, barley and soya on the bioavailability of dietary phosphorus, calcium, magnesium, zinc and protein in piglets. Agribio. Res., pp. 39-47.

Pintar J., Homen B., Gazic K., Janjecic Z., Sikiric M. and Cerny T. 2005. Effect of supplemental phytase on nutrient excretion and retention in broilers fed different cereal based diets. Czech J. Animal Sci., 50(1), 40-46.
Reitman M.D. and Frankel S. 1957. A Colorimetric Method for the Determination of Serum Glutamic Oxalacetic and Glutamic Pyruvic Transaminases. American J. of Clinical Pathology, 28(Issue 1), 56-63.

Samejima M. 1990. Principal component analysis of measurements in the skeleton of red jungle fowl and 12 breeds of domestic fowls, 3: Ossa membripelvini. Japanese Poultry Sci., 27, 142161.

SAS 1998. Statistical Analysis System, SAS User's Guide: Statistics Ver. $6.04,4^{\text {th }}$ ed. SAS Institute. Inc.,Cary, NC. USA.

Seedor J.G., Quarruccio H.A. and Thompson D.D. 1991. The biophosphonate alendronate (MK-217) inhibits bone loss due to ovariectomy in rats. J. of Bone and Mineral Research, 6, 339-346.

Selle P.H. and Ravindran V. 2007. Microbial phytase in poultry nutrition. Animal Feed Sci. Technol., 135, 1-41.

Slominski B.A. 2011. Recent advances in research on enzymes for poultry diets (Review). Poultry Sci., 90, 2013-2023.

Srikanthithasan K., Macelline S.P., Wickramasuriya S.S., Tharangani H., Ang L., Jayasena D.D. and Heo J.M. 2020. Effects of adding phytase from aspergillus niger to a low phosphorus diet on growth performance, tibia characteristics, phosphorus excretion, and meat quality of broilers 35 days after hatching. J. Poult. Sci., 57, 28-36.

Thabet H.A. 2010. Effect of high concentration of cholecalciferol in deficient calcium and phosphorus broiler diets on productive performance and carcass quality. Ph.D. Thesis, Fac. of Agric., Ain Shams Univ., Egypt. pp. 52-55.

Thabet H.A., Abdelaziz M.A.M. and Shourrap M.I. 2014. Effect of dietary restriction of calcium and phosphorus on broiler performanceand bone characteristics. Egyptian J. Nutrition and Feeds, 17(2), 301-314.

Thacker P.A., Deep A., Petri D. and Warkentin T. 2013. Nutritional evaluation of lowphytate peas (Pisum sativum L.) for young broiler chicks. Arch. Anim. Nutr. 67, 1-14.

Tietz N.W. 1995. Clinical Guide to Laboratory Tests, 3rd Edi. W.B. Saunders Co. Philadelphia, PA., USA., pp. 131-140. 
Walk C.L., Addo-Chidie E.K., Bedford M.R. and Adeola O. 2012. Evaluation of a highly soluble calcium source and phytase in the diets of broiler chickens. Poult. Sci., 91, 2255-2263.

Walk C.L., Bedford M.R., Santos T.T., Paiva D., Bradley J.R., Wladecki H. and Honake C. and McElroy A.P. 2013. Extra-phosphoric effects of super doses of a novel microbial phytase. Poultry Sci., 92, 719-725.
Xian R.J., Fa H., Luo M.R., Valentino B., Shu G.W., Hai J.Z. Hong Y.Y. and Guang H. Qi 2013. Effects of Non-Phytate Phosphorus Levels and Phytase Sources on Growth Performance, Serum Biochemical and Tibia Parameters of Broiler Chickens. Italian J. of Animal Sci., 60, 3-12.

Yan F., Angel R., Ashwell C., Mitchell A. and Christman M. 2005. Evaluation of the broiler's ability to adapt to an early moderate deficiency of phosphorus and calcium. Poultry Sci., 84, 1232-1241. 


\begin{tabular}{|c|c|c|}
\hline & 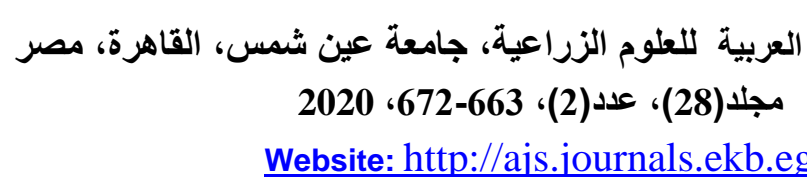 & arding \\
\hline 672 & & \\
\hline
\end{tabular}

\section{تأثيراضافة إنزيم الفيتيز لعلائق بداري التسمين المنففضة في الكالسيوم والفوسفور على الآداء الإنتاجي وصفات العظام}

[49]

$$
\begin{aligned}
& \text { ياسر سعد شعبان1" - فتحي عبدالعظيم1 - هاني على ثابت1- آمال محمد حسن2 } \\
& \text { 1-قسم إنتاج الدواجن- كلية الزراعة - جامعة عين شمس - ص.ب } 68 \text { - حدائق شبرا } 11241 \text { - القاهرة - مصر }
\end{aligned}
$$

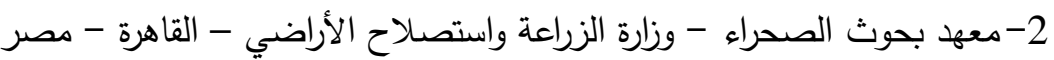

*Corresponding author: yassor saad@yahoo.com

Received 26 March, 2020

Accepted 13 May, 2020

(75/75) مغذاه على بادى

(50/75) مغذاه على بادى

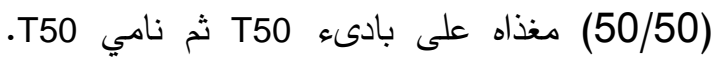

احتوت كل معاملة على 30 طائر مقسمة الى 3 تكرارات

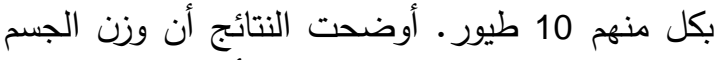

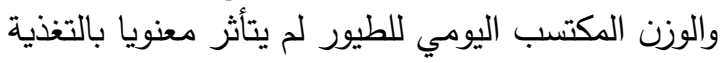
على علائق منخفضة في الكالسيوم والفوسفور حتى لرئي

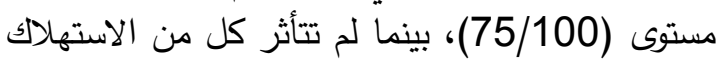

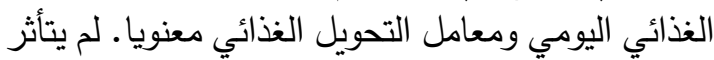

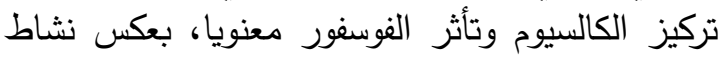
إنزيم GOT GOT في بلازما الدم الذي لم يتأثر معنويا

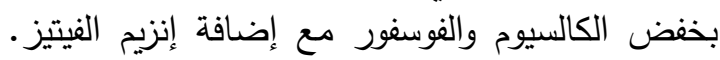

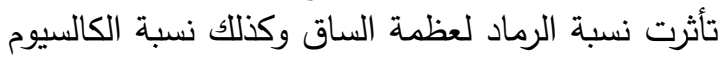
والفوسفور معنويا بخفض الكالسيوم والفوسفور • بنفس التفاد الاتجاه، فقد تأثرت قوة كسر عظمة العات الساق بتأثير

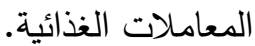

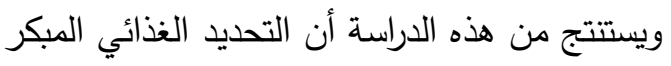
لعنصري الكالسيوم والفوسفور مع إضافة إنزيم الفيتيز

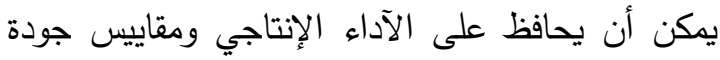

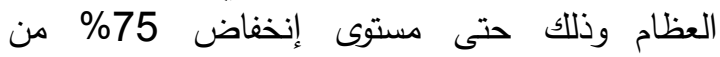
الاحتياجات من العنصرين خلال فترة النامي.

الكلمات المفتاحية: إنزيم الفيتيز، كالسيوم، فوسفور، الإني

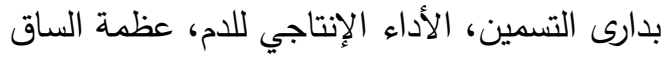

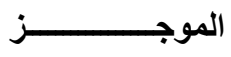

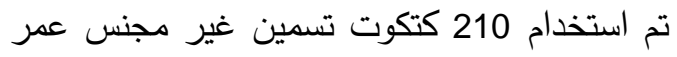

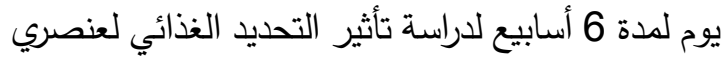

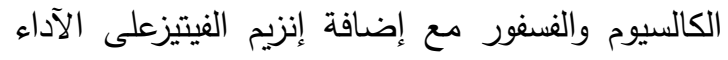

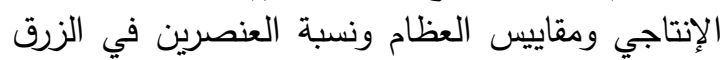
لبداري التسمين. استخدمت ثثلاث علائق بادئ في الفترة

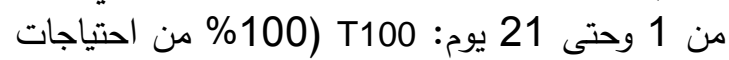

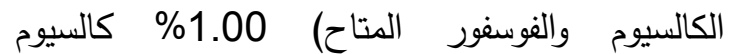

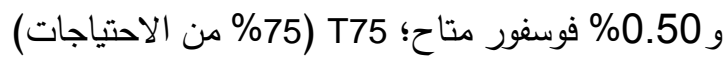

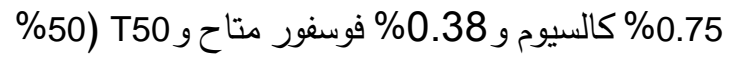

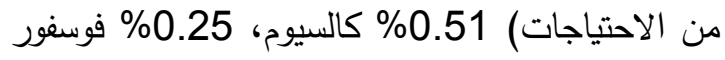

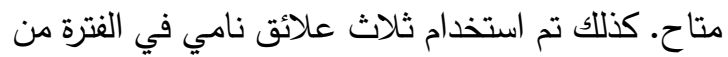

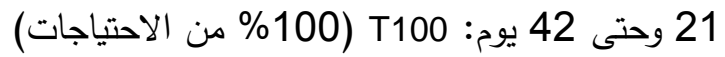

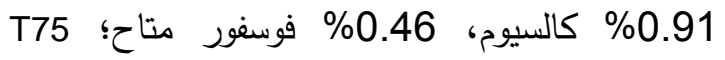

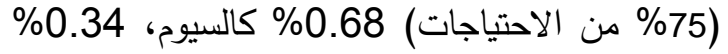

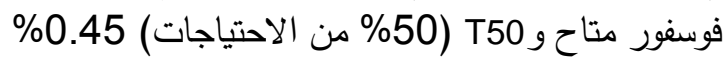

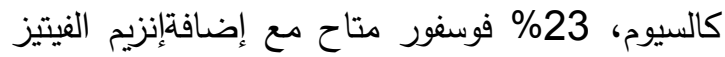

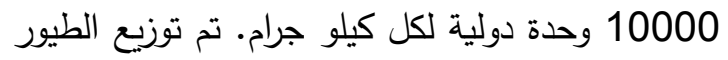
على سبع معاملات غذائية على أساس ما يغذى دلى عليه الطيور في مرحلتي البادئ والنامي بالتتابع لتكون التئي

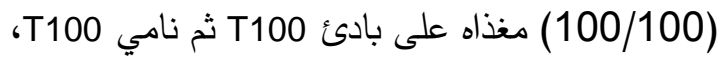

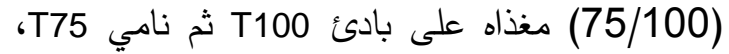

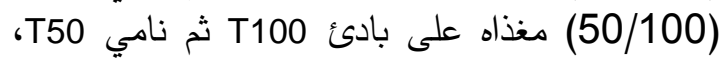

